Original Article

\title{
COMPARATIVE STUDY OF RP-HPLC METHOD VERSUS FOURIER TRANSFORM CONVOLUTION CHEMOMETRIC METHODS; AN APPLICATION ON PHARMACEUTICAL BINARY MIXTURES OF CANDESARTAN CILEXETIL-PITAVASTATIN CALCIUM AND CLOPIDOGREL BISULFATE- ROSUVASTATIN CALCIUM
}

\author{
MARWA K. EL JAMAL*, AZZA A. GAZY \\ Department of Pharmaceutical Technology, Faculty of Pharmacy, Beirut Arab University, Beirut, Lebanon \\ Email: Marwa.jamal@bau.edu.lb
}

Received: 18 May 2016 Revised and Accepted: 12 Aug 2016

\begin{abstract}
Objective: A comparative study of smart spectrophotometric chemometric assisted techniques and RP-HPLC for the determination of candesartan cilexetil (CAN)-pitavastatin calcium (PIT) and clopidogrel bisulfate (CLO)-rosuvastatin calcium (ROS), binary co-administered drugs were developed and validated.
\end{abstract}

Methods: The spectrophotometric chemometric assisted methods included two simple techniques, namely Fourier transform convolution (FF) and ratio spectra of Fourier transform convolution (FFR) methods. FFR is considered as a hybrid divisor ratio spectra method where Fourier functions are applied to divisor ratio signals. The RP-HPLC method involves a rapid separation on a $\mathrm{C}_{18}$ column using a mobile phase consisting of acetonitrile: sodium dihydrogen phosphate (adjusted to $\mathrm{pH} 2.6$ using orthophosphoric acid) in the ratio of 70:30 v/v at a flow rate of $1 \mathrm{ml} / \mathrm{min}$ in isocratic mode. CLO and ROS were monitored at $220 \mathrm{~nm}$ however CAN and PIT were monitored at $238 \mathrm{~nm}$.

Results: The spectrophotometric chemometric assisted methods proved their ability to quantify each of the studied drugs in their binary mixtures, where excellent percentage recoveries were obtained. FF and FFR method proved to be linear over the concentration range of $10-50 \mu \mathrm{g} / \mathrm{ml}$ for CLO, 4-20 $\mu \mathrm{g} / \mathrm{ml}$ for ROS, $8-20 \mu \mathrm{g} / \mathrm{ml}$ for CAN and $2-10 \mu \mathrm{g} / \mathrm{ml}$ for PIT. The RP-HPLC method was able to separate the drugs in the study; retention times were found to be $3.9 \mathrm{~min}$ and $14.4 \mathrm{~min}$ for ROS-CLO, $4.2 \mathrm{~min}$ and $14.5 \mathrm{~min}$ for PIT-CAN respectively. The RP-HPLC method was found to be linear in the concentration range of $0.1-0.5 \mu \mathrm{g} / \mathrm{ml}$ for CLO, $0.04-0.2 \mu \mathrm{g} / \mathrm{ml}$ for ROS, $0.5-1 \mu \mathrm{g} / \mathrm{ml}$ for CAN and $0.05-0.1 \mu \mathrm{g} / \mathrm{ml}$ for PIT. System suitability parameters proved that peaks were well resolved from each other.

Conclusion: The spectrophotometric and chromatographic methods were validated according to ICH guidelines. Recovery was found to be in the range of $95.9 \%-100.5 \%$ in synthetic laboratory mixtures. The suggested spectrophotometric methods have the advantage over other methods that they do not require a preliminary separation. Statistical analysis between the suggested spectrophotometric chemometric assisted and RP-HPLC methods, using student's t-and F-test revealed that there is no difference between the applied methods.

Keywords: Co-administered drugs, Rosuvastatin-clopidogrel, Pitavastatin-candesartan, Fourier function ratio spectra, RP-HPLC, Spiked plasma

(C) 2016 The Authors. Published by Innovare Academic Sciences Pvt Ltd. This is an open access article under the CC BY license (http://creativecommons. org/licenses/by/4. 0/) DOI: http://dx.doi.org/10.22159/ijpps.2016v8i10.12931

\section{INTRODUCTION}

Cardiovascular disease is the major cause of mortality and affects many individuals health. Many patients with cardiovascular diseases require polytherapy where drug combination could be widely available for primary prevention. Combining statins with antihypertensives or anticoagulants is beneficial in preventing myocardial infarction and stroke [1]. Establishing analytical methods for the estimation of mixtures of cardiovascular coadministered drugs would be of great importance [1].

Clopidogrel bisulfate chemically is, (methyl (2S)-2-(2-chlorophenyl)2-(6,7-dihydro-4H-thieno[3,2-c]pyridin-5-yl) acetate; sulfuric acid) (fig. 1). It is a new thienopyridine compound structurally related to ticlopidine. It is indicated for the reduction of atherosclerotic events in patients with atherosclerosis. Clopidogrel inhibits platelet aggregation by selective preventing of the binding adenosine diphosphate (ADP) to its platelet receptor. It is a potent antiplatelet drug used in thromboembolic disorders [2].

Rosuvastatin Calcium (ROS) chemicallyis, (3R, 5S, 6E)-7-[4-(4fluorophenyl)-2-( $N$-methyl-methane-sulfonamido)-6-(propan-2-yl) pyrimidin-5-yl]-3,5-dihydroxyhept-6-enoic acid (fig. 2). Rosuvastatin reduces cholesterol by increasing the number of low-density lipoprotein (LDL) receptors on the cell-surface to enhance uptake and catabolism of LDL. It also inhibits hepatic synthesis of hepatic very-low-density lipoprotein (VLDL), which reduces the total number of VLDL and LDL particles. The treatment reduces triglycerides (TG) and produces increases in high-density lipoprotein cholesterol (HDL-C) [3].

Candesartan Cilexitil chemically is, (2-ethoxy-1-(\{4-[2- $(2 H-1,2,3,4-$ tetrazol-5-yl)phenyl]phenyl\}methyl)-1 $H$-1,3-benzodiazole-7-carboxylic acid) [2] (fig. 3), belongs to the angiotensin II antagonists. Angiotensin II causes the peripheral blood vessels to narrow and stimulates the production of a hormone called aldosterone.

Aldosterone causes salt and water to be retained by the kidneys, which increases the volume of fluid in the blood vessels. Candesartan blocks the receptors that angiotensin II acts on, so that the peripheral blood vessels are allowed to widen consequently a decrease in the blood pressure occurs [3].

Pitavastatin Calcium chemically is 3-Hydroxy-3-methylglutaryl coenzyme A (HMG-CoA) reductase inhibitors (statins) (fig. 4), inhibit the synthesis of mevalonate, a rate-limiting step in cholesterol level.

Competitive inhibition of HMG-CoA reductase by the statins decreases hepatocyte cholesterol synthesis, which results in increased extraction of LDL-C from the blood and decreases circulating LDL-C concentrations. High plasma LDL-cholesterol is a risk factor for cardiovascular diseases and, therefore, cholesterollowering drugs are used to prevent them. Some randomized controlled trials have shown that statins have potent cholesterollowering effects and reduce the risk of cardiovascular diseases in everyday medical practice [4]. 
<smiles>COC(=O)[C@@H](c1ccccc1Cl)N1CCc2sccc2C1</smiles>

$\mathrm{H}_{2} \mathrm{SO}_{4}$

Fig. 1: Clopidogrel bisulphate<smiles>CCc1nc(N(C)C)nc(-c2ccc(F)cc2)c1/C=C/C(O)CC(O)CC(=O)O</smiles>

Fig. 2: Rosuvastatin calcium<smiles>CCOc1nc2cccc(C(=O)OC(C)OC(=O)OC3CCCCC3)c2n1Cc1ccc(-c2ccccc2-c2nnn[nH]2)cc1</smiles>

Fig. 3: Candesartan cilexetil

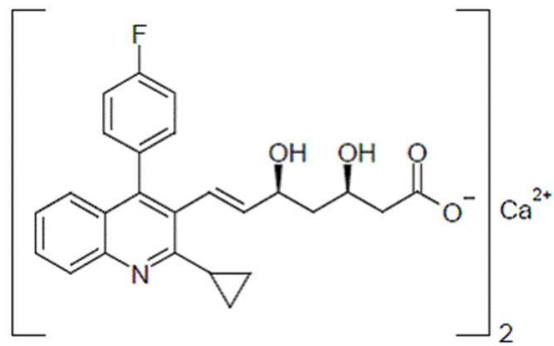

Fig. 4: Pitavastatin calcium

Literature revealed a variety of analytical methods for the determination of CLO alone or in combination with other drugs. CLO was determined alone by spectrophotometry [5], HPLC [6], LC-MS [7], LC-MS-MS[8]. CLO has also been assayed in combination with other drugs by spectrophotometry[9], chemometric methods [10, 11], HPLC [12].

Several methods has been published for the determination of Rosuvastatin Calcium, including spectrophotometry [13], HPLC [14, 15], RP-UPLC [16]. In combination with other drugs rosuvastatin has been determined by HPLC [17-19], chemometry in the presence of its degradation product [20].

Various analytical procedures have been established for the quantitative determination of Candesartan Cilexetil in drug products singly or in combination. Candesartan Cilexetil was determined by spectrophotometry alone [21] or in combination $[22,23]$.

Several chemometric methods have also been developed for its quantification, including Fourier Functions [24], classical least square [25], Q-analysis [26], derivative spectrophotometry [27]. It has also been determined by LC/MS/MS in human plasma [28].

Pitavastatin Calcium has been determined by several analytical methods such as HPLC [29], spectrophotometry [30].
To the best of our knowledge, neither of the already published methods has been related to an RP-HPLC method optimization for simultaneous determination of CLO-ROS or PIT-CAN. There is also, no chemometric method, using discrete Fourier transform convolution, reported for the simultaneous estimation of CLO-ROS nor for PIT-CAN in combination forms. The aim of this study was to develop selective, sensitive and accurate methods, which can determine both components simultaneously.

\section{MATERIALS AND METHODS}

\section{Apparatus}

The spectrophotometric measurements were carried out on a Jasco V-530 double beam UV-Vis Spectrophotometer connected to a computer loaded with Jasco UVPC software and HP Deskjet 5652 printer. The absorption spectra were measured using 1-cm quartz cells. For FF and FFR, the absorption spectra were recorded using 1 cm quartz cells.

HPLC system (waters 1525) is composed of binary HPLC pump, connected to water 2487 dual wavelength absorbance detector. The liquid chromatographic system is equipped with waters 717 plus autosampler. Liquid separations are performed on RPC Sunfire (C) C18 analytical column (250 x $4.6 \mathrm{~mm} \times 5 \mu \mathrm{m})$ at ambient temperature. The mobile phase used was degassed and filtered by passing through $0.5 \mu \mathrm{m}$ pore size membrane filter at a pumping speed of 30L/min (Glassco diaphragm Vacuum pump). The samples were also filtered using PTFE $0.2 \mu \mathrm{m}$ Minisart SRP 15 (Sartorius Stedim) disposable filters.

\section{Materials and reagents}

Clopidogrel bisulfate (Sanofi Pharma Bristol-Myers Squibb SNC, France); rosuvastatin calcium (Astrazeneca, UK. IPR pharmaceuticals Inc. Canovanas, Puerto Rico); candesartan cilexetil, AstraZeneca AB, Sodertalje, Sweden); pitavastatin calcium (ALGORITHM S. A. L, Zouk Mosbeh, Lebanon); acetonitrile (SIGMAALDRICH CHROMASOLV ${ }^{\circledR F O R ~ H P L C>99.9 \%), ~} \mathrm{KH}_{2} \mathrm{PO}_{4}$ (Merck KGaA), $\mathrm{Na}_{2} \mathrm{HPO}_{4}$ (BDH); human plasma was supplied by Dar Al Ajaza.

\section{Chromatographic conditions}

The mobile phase was prepared by mixing potassium dihydrogen phosphate buffer (adjusted to $\mathrm{pH} 2.6$ with orthophosphoric acid) and acetonitrile in a ratio (30:70) by volume.

Standard stock solutions for RP-HPLC and chemometric methods

Preparation of CLO standard solution: $1000 \mu \mathrm{g} / \mathrm{ml}$ stock solution was prepared by accurately dissolving $50 \mathrm{mg}$ of CLO into $50-\mathrm{mL}$ volumetric flask using methanol as solvent.

Preparation of ROS standard solution: $200 \mu \mathrm{g} / \mathrm{ml}$ stock solution was prepared by accurately dissolving $20 \mathrm{mg}$ of ROS into $100-\mathrm{mL}$ volumetric flask using methanol as solvent.

Preparation of PIT standard solution: $200 \mu \mathrm{g} / \mathrm{ml}$ stock solution was prepared by accurately dissolving $20 \mathrm{mg}$ of PIT into $100-\mathrm{mL}$ volumetric flask using methanol as solvent.

Preparation of CAN standard solution: $200 \mu \mathrm{g} / \mathrm{ml}$ stock solution was prepared by accurately dissolving $20 \mathrm{mg}$ of CAN into $100-\mathrm{mL}$ volumetric flask using methanol as solvent.

\section{Chemometric assisted spectrophotometric methods}

\section{Working standard solutions}

Portions of the stock standard solutions were separately diluted with methanol to attain the concentration range of $100 \mu \mathrm{g} / \mathrm{ml} \mathrm{CLO}$, $40 \mu \mathrm{g} / \mathrm{ml} \mathrm{ROS}, 20 \mu \mathrm{g} / \mathrm{ml}$ PITA and $80 \mu \mathrm{g} / \mathrm{ml}$ CAN.

\section{Calibration graphs}

Accurate volumes 1-5 ml (1-mL step) of the standard solutions of CLO, ROS, PIT and CAN into five separate sets of $10-\mathrm{mL}$ calibrated flasks were transferred and completed to volume with methanol to obtain a calibration of $10-50 \mu \mathrm{g} / \mathrm{ml}$ for CLO, $4-20 \mu \mathrm{g} / \mathrm{ml}$ for ROS, 2 - 
$10 \mu \mathrm{g} / \mathrm{ml}$ of PIT and 8-20 $\mu \mathrm{g} / \mathrm{ml}$ of CAN. The absorbance values for each solution at 1-nm intervals in the wavelength range $225-275 \mathrm{~nm}$ for CLO-ROS mixture and $230-300 \mathrm{~nm}$ for PIT-CAN mixture were recorded.

\section{Synthetic mixtures}

Accurate volumes of each of CLO, ROS, PIT or CAN standard solutions were transferred into $10 \mathrm{ml}$ volumetric flasks and diluted with methanol to prepare 6 synthetic mixtures containing $30 \mu \mathrm{g} / \mathrm{ml}$ CLO with $4 \mu \mathrm{g} / \mathrm{ml}, 8 \mu \mathrm{g} / \mathrm{ml}, 12 \mu \mathrm{g} / \mathrm{ml}, 16 \mu \mathrm{g} / \mathrm{ml}$ or $20 \mu \mathrm{g} / \mathrm{ml} \mathrm{ROS}$.

\section{RP-HPLC method}

\section{Working standard solutions}

Portions of the stock standard solutions were separately diluted with methanol to attain the concentration range of $1 \mu \mathrm{g} / \mathrm{ml} \mathrm{CLO}, 0.4$ $\mu \mathrm{g} / \mathrm{ml}$ ROS, $0.4 \mu \mathrm{g} / \mathrm{ml}$ PITA and $1 \mu \mathrm{g} / \mathrm{ml} \mathrm{CAN}$.

\section{Calibration graphs}

\section{Pure drugs}

Into series of separate 10-mL measured flasks, aliquots of 1-5 ml from standard solutions of CLO, ROS, PIT or CAN were transferred and diluted to volume with methanol to give the final concentrations of $0.1-0.5 \mu \mathrm{g} / \mathrm{ml}$ for CLO $0.04-0.2 \mu \mathrm{g} / \mathrm{ml}$ for ROS, $0.5-1 \mu \mathrm{g} / \mathrm{ml}$ for CAN and $0.05-0.1 \mu \mathrm{g} / \mathrm{ml}$ for PIT. The above solutions were filtered using $0.2 \mu \mathrm{m}$ disposable filters. $20 \mu \mathrm{L}$ portions of the working solutions of CLO, ROS, PIT or CAN were injected in triplicates and chromatographed under the chromatographic conditions mentioned above. The peak area values of each drug were plotted against the corresponding concentrations to obtain the calibration graph for each drug. The concentrations of CLO, ROS, PIT and CAN from the corresponding calibration graphs were computed.

\section{Spiked plasma}

Calculated volumes of the working solutions of CLO, ROS, PIT and CAN, were added to $1 \mathrm{ml}$ of human plasma and $1 \mathrm{ml}$ of acetonitrile, to produce a final concentration in the range of 0.1$0.5 \mu \mathrm{g} / \mathrm{ml}$ for CLO, $0.04-0.2 \mu \mathrm{g} / \mathrm{ml}$ for ROS, $0.5-1 \mu \mathrm{g} / \mathrm{ml}$ for CAN and $0.05-0.1 \mu \mathrm{g} / \mathrm{ml}$ for PIT. After vortex mixing and centrifugation $(6000 \mathrm{rpm} / \mathrm{min})$, the supernatant solutions were filtered using $0.2 \mu \mathrm{m}$ disposable filters transferred to separate Eppendorf tubes and $20 \mathrm{uL}$ of each were injected into the HPLC column. The peak areas for each drug were measured and the corresponding concentrations were derived referring to calibration graph.

\section{Synthetic mixtures}

\section{Laboratory prepared mixtures}

Accurate volumes of working standard solutions of CLO, ROS, PIT and CAN were transferred into six separate $10-\mathrm{ml}$ calibrated flasks and diluted to the mark with methanol to give five synthetic mixtures containing CLO: ROS or PIT: CAN in the ratios of 0.3:0.04 $\mu \mathrm{g} / \mathrm{ml}, 0.3: 0.08 \mu \mathrm{g} / \mathrm{ml}, 0.3: 1.2 \mu \mathrm{g} / \mathrm{ml}, 0.3: 1.6 \mu \mathrm{g} / \mathrm{ml}, 0.3: 2 \mu \mathrm{g} / \mathrm{ml}$. The solutions were filtered using $0.2 \mu \mathrm{m}$ disposable filters. Volumes of $20 \mu \mathrm{L}$ portions of the mixture solutions were injected in triplicates and chromatographed under the chromatographic conditions mentioned above. The peak areas for each drug were measured and the corresponding concentrations in the mixtures were derived referring to calibration graph.

\section{Spiked plasma}

Accurate volumes (from the supernatant layer obtained from centrifugation) of each drug were pipetted into Eppendorf tubes to give synthetic mixtures containing CLO: ROS or PIT: CAN in the ratios of $0.3: 0.04 \mu \mathrm{g} / \mathrm{ml}, 0.3: 0.08 \mu \mathrm{g} / \mathrm{ml}, 0.3: 1.2 \mu \mathrm{g} / \mathrm{ml}, 0.3: 1.6 \mu \mathrm{g} / \mathrm{ml}$, $0.3: 2 \mu \mathrm{g} / \mathrm{ml}$. Volumes of $20 \mu \mathrm{L}$ portions of the mixture solutions were injected in triplicates and chromatographed under the chromatographic conditions mentioned above. The peak areas for each drug were measured and the corresponding concentrations in the mixtures were derived referring to calibration graph.

\section{RESULTS AND DISCUSSION}

\section{Chemometric assisted spectrophotometric methods}

Fig. 5 and 6 represent the absorption spectra of CLO-ROS and PITCAN, respectively. The spectral overlapping between the absorption spectra of both mixtures is sufficient to demonstrate the difficulty to resolve such mixtures using traditional UV method. The main aim of this work is to resolve the spectral overlapping of CLO-ROS and CAN-PIT and simultaneously determine the two co-administered mixtures in the laboratory made mixtures. This was achieved by applying FF and FFR methods.

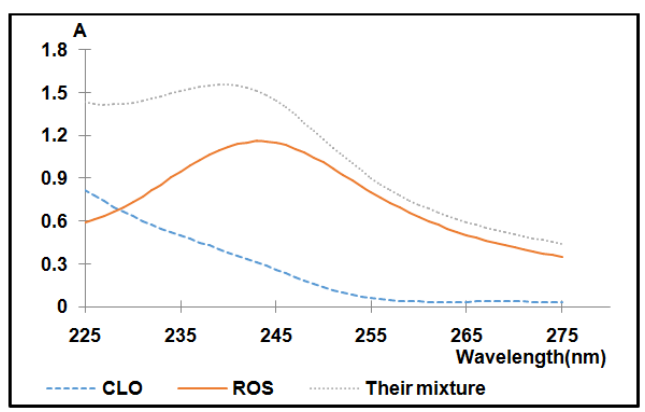

Fig. 5: Absorption curves of $30 \mu \mathrm{g} / \mathrm{mICLO}$ in methanol, 30 $\mu \mathrm{g} / \mathrm{mlof}$ ROS in methanol and their mixture

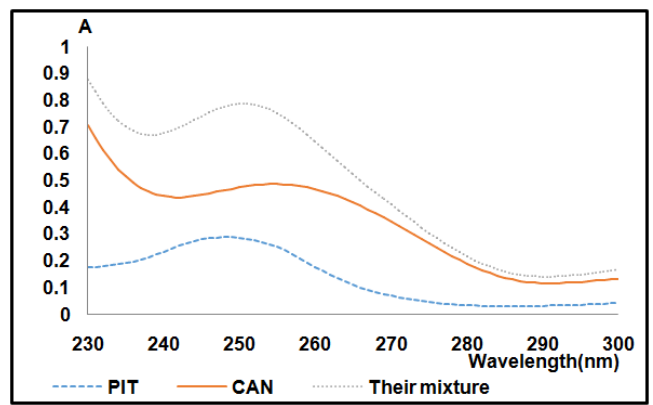

Fig. 6: Absorption curves of $4 \mu \mathrm{g} / \mathrm{mlPIT}$ in methanol, $16 \mu \mathrm{g} / \mathrm{ml}$ of CAN in methanol and their mixture

Discrete Fourier Transform Convolution (FF) and its ratio derivative (FFR), depend on deriving the convoluted absorption spectra of CLO and ROS using combined trigonometric Fourier function (FF) and application of Ratio spectra derivative of Fourier function (FFR). Following the general rules for the use of Fourier function in the processing of absorption spectral data [31, 32], the associated different parameters were optimized. These include the selection of function order, number of points and wavelength intervals corresponding to spectral characteristics. The optimum parameters were selected for each drug in order to give precise and accurate results for both analytes in the presence of each other.

CLO was determined in the presence of ROS by applying Fourier functions (FF) and the ratio spectra derivative of Fourier functions (FFR). Both methods gave good \% recoveries. The following equations were applied for FF (eq. 1) and FFR (eq. 2), respectively:

$$
t_{j}^{\prime}=\left[(1) \mathrm{A}_{0-}(1) \mathrm{A}_{1}-(1) \mathrm{A}_{2}+(1) \mathrm{A}_{3}+(1) \mathrm{A}_{4-}-(1) \mathrm{A}_{5-}(1) \mathrm{A}_{6+}(1) \mathrm{A}_{7}\right] / 4 \ldots \ldots \ldots \ldots \ldots
$$

Where $\mathrm{A}_{0}-\mathrm{A}_{7}$ stand for eight absorbance values at 4-nm intervals for CLO and ROS within the range (241-269 $\mathrm{nm}$ ). The numbers in brackets are the selected combined Fourier functions and $\mathrm{T}^{\prime}=[\cos$ $\left.2 x_{i}+\cos \left(2 x_{i+} 45^{\circ}\right)\right]$ (fig. 7).

$$
t_{j}^{\prime}=\left[(1.5) \mathrm{FFR}_{0+}(0) \mathrm{FFR}_{1}-(1.5) \mathrm{FFR}_{2}-\right.
$$

(1.5)FFR $\left.3+(0) \mathrm{FFR}_{4}+(1.5) \mathrm{FFR}_{5}\right] / 3 \ldots \ldots \ldots \ldots . . .(2)$ 
Where FFR ${ }_{0}-F_{F R}$ stand for six FF ratio signals at 4-nm intervals for CLO and ROS within the range (241-261 nm). The numbers in brackets are the selected combined Fourier functions and $\mathrm{T}^{\prime}=[\cos$ $\left.x_{i}+\cos \left(x_{i+} 60^{\circ}\right)\right]$ (fig. 8).

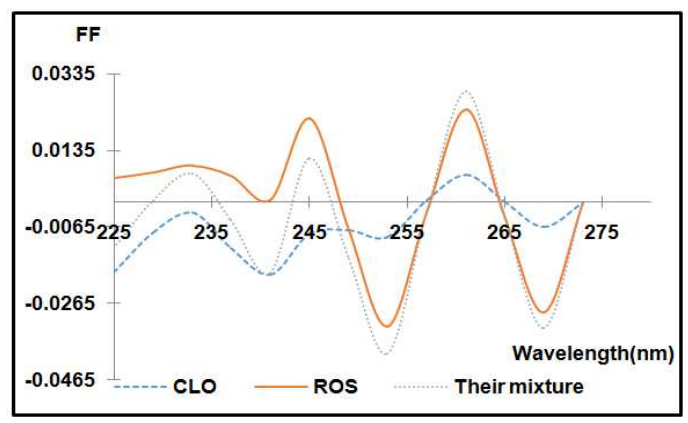

Fig. 7: Fourier Functions convoluted curves for $30 \mu \mathrm{g} / \mathrm{mICLO}$ in methanol, $8 \mu \mathrm{g} / \mathrm{mlROS}$ in methanol and their mixture

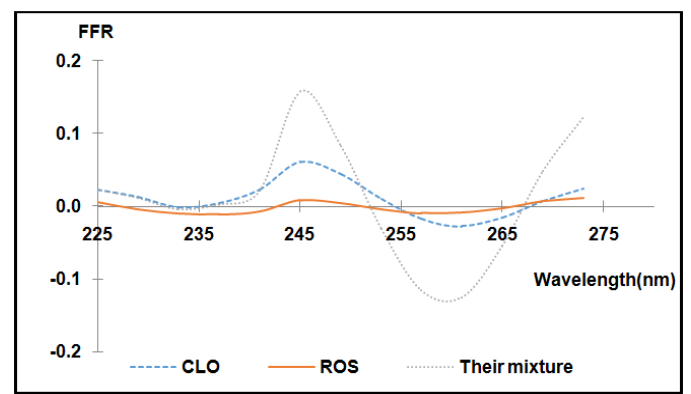

Fig. 8: Fourier Functions convoluted curves of derivative ratio for $30 \mu \mathrm{g} / \mathrm{ml} \mathrm{CLO}$ in water, $8 \mu \mathrm{g} / \mathrm{ml}$ ROS in methanol and their mixture

CAN was also determined in the presence of PIT by applying FF and FFR were good \% recoveries were obtained by applying both methods. The following equations were applied for FF and FFR, (eq. $3,4)$ respectively:

$$
\begin{gathered}
t_{j}^{\prime}=\left[(1.707) \mathrm{A}_{0+}(0.707) \mathrm{A}_{1}-(0.707) \mathrm{A}_{2}-(1.707) \mathrm{A}_{3}-(1.707) \mathrm{A}_{4}-(0.707)\right. \\
\left.\mathrm{A}_{5}+(0.707) \mathrm{A}_{6+}(1.707) \mathrm{A}_{7}\right] / 4 \ldots \ldots \ldots \ldots . .(3) .
\end{gathered}
$$

Where $\mathrm{A}_{0}-\mathrm{A}_{7}$ stand for eight absorbance values at 6-nm intervals for PIT and CAN within the range $(236-278 \mathrm{~nm})$. The numbers in brackets are the selected combined Fourier functions and $\mathrm{T}^{\prime}=[\cos$ $\left.x_{i}+\cos \left(x_{i+} 45^{\circ}\right)\right]$ (fig. 9).

$$
\begin{aligned}
& t_{j}^{\prime}=\left[(1.5) \mathrm{FFR}_{0+}(0) \mathrm{FFR}_{1}-(1.5) \mathrm{FFR}_{2}-\right. \\
&\left.(1.5) \mathrm{FFR}_{3}+(0) \mathrm{FFR}_{4}+(1.5) \mathrm{FFR}_{5}\right] / 3 \ldots \ldots \ldots \ldots
\end{aligned}
$$

Where $\mathrm{FFR}_{0}-\mathrm{FFR}_{5}$ stand for six FF ratio signals at 4-nm intervals for PIT and CAN within the range $(258-278 \mathrm{~nm})$. The numbers in brackets are the selected combined Fourier functions and $\mathrm{T}^{\prime}=[\cos$ $x_{i}+\cos \left(x_{i+} 60^{\circ}\right)$ ] (fig. 10).

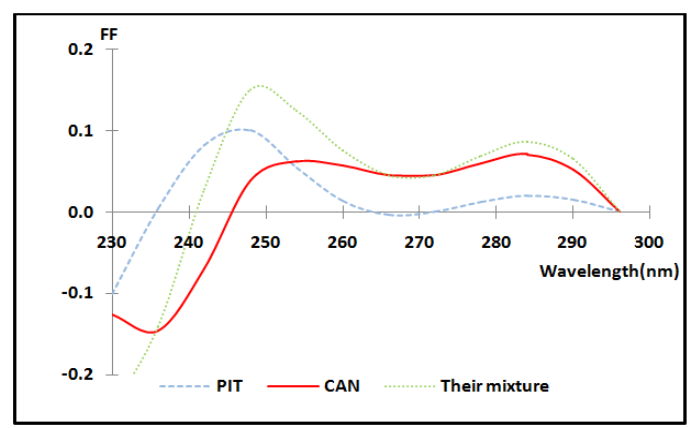

Fig. 9: Fourier Functions convoluted curves for $4 \mu \mathrm{g} / \mathrm{mlPIT}$ in methanol, $16 \mu \mathrm{g} / \mathrm{ml}$ CAN in methanol and their mixture

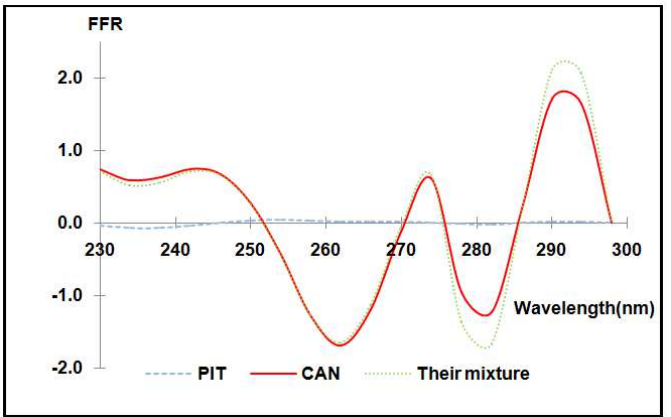

Fig. 10: Fourier functions convoluted curves of First derivative ratio for $4 \mu \mathrm{g} / \mathrm{mlPIT}$ in methanol, $16 \mu \mathrm{g} / \mathrm{ml} \mathrm{CAN} \mathrm{in} \mathrm{methanol}$ and their mixture

\section{RP-HPLC method}

RP-HPLC method was developed to provide a suitable procedure for the simultaneous determination of CAN-PIT and CLO-ROS in the coadministered laboratory made mixtures and in spiked plasma. The most important aspect of RP-HPLC method is the achievement of sufficient resolution with acceptable peak symmetry in reasonable time. To achieve this goal, preliminary investigations were directed towards the effect of various variables (mobile phase composition, flow rate, and $\mathrm{pH}$ ) on the system suitability to maximize the resolution and sensitivity of the analytical procedure. Different mobile phases were tried, the use of acetonitrile in the mobile phase allowed the elution of CLO-ROS and PIT-CAN at reasonable retention time. Trials were carried out with respect to change in the ratio of constituents of the mobile phases (acetonitrile: phosphate buffer) as $40: 60,45: 55,50: 50,60: 40$, all of them gave very long retention times. The optimal mobile phase composition was found to be in the ratio of (70:30) for both mixtures.

Different $\mathrm{pH}$ values of the aqueous mobile phase were tried including 2.6, 3.3, 3.6, 4.5 and 5.5. Alkaline $\mathrm{pH}$ gave very long retention time. Strongly acidic $\mathrm{pH}$ values gave peaks of acceptable retention time that did not interfere with plasma protein peaks. So, the best separation in terms of system suitability and the resolution was achieved by using the value of $\mathrm{pH}$ of 2.6. So, a mobile phase composition of acetonitrile: phosphate buffer (70:30) at $\mathrm{pH} 2.6$ was found to provide optimum separation with good resolution and the most symmetric well-defined peaks (table 1). The optimum wavelength for detection was $220 \mathrm{~nm}$ for CLO-ROS and $238 \mathrm{~nm}$ for PIT-CAN at which much better detector response was obtained

The optimal mobile phase composition was found to be in the ratio of (70:30, acetonitrile: phosphate buffer) at $\mathrm{pH} 2.6$ for both mixtures. The wavelength used for detection was $220 \mathrm{~nm}$ for CLOROS and $230 \mathrm{~nm}$ for PIT-CAN. Fig. 11, shows the separation of ROS at $3.9 \mathrm{~min}, \mathrm{CLO}$ at $14.0 \mathrm{~min}$.

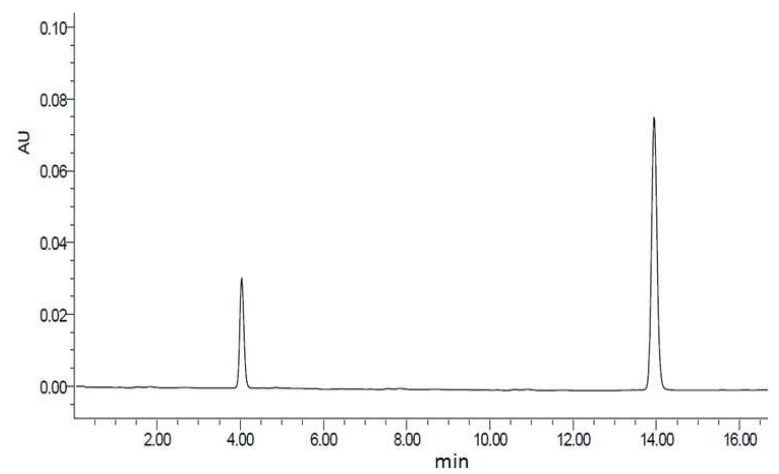

Fig. 11: HPLC chromatogram of a $20 \mu$ injection of a standard mixture of $40 \mu \mathrm{g} / \mathrm{ml} \mathrm{CLO}$ and $10 \mu \mathrm{g} / \mathrm{ml}$ ROS using the optimized chromatographic conditions 
Fig. 12, shows the separation of PIT at 4.2 and CAN at 14.5 min, at the optimized chromatographic conditions. Fig. 13 and 14, shows the separation of ROS at $4.3 \mathrm{~min}, \mathrm{CLO}$ at $14.6 \mathrm{~min}$, PIT at 4.4 and CAN at $14.3 \mathrm{~min}$, in spiked plasma at the optimized chromatographic conditions, respectively. All the peaks were well resolved and not interfering with plasma protein peaks, with good peak shape and symmetry. The optimum chromatographic conditions mentioned previously were applied for all measurements. All the peaks were well resolved and not interfering with plasma protein peaks, with good peak shape and symmetry.

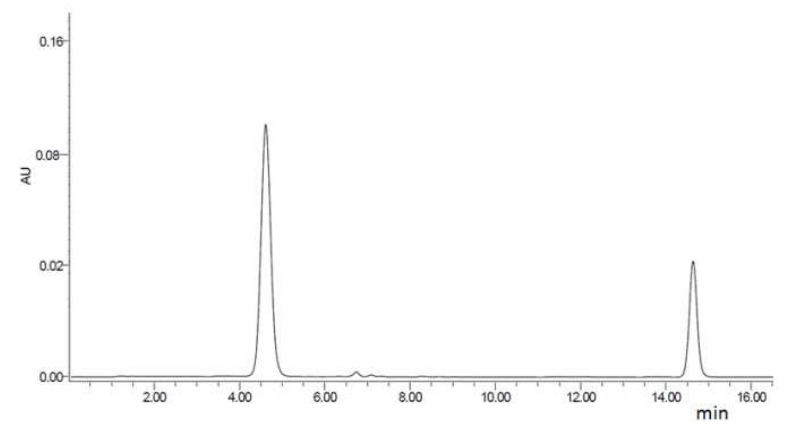

Fig. 12: HPLC chromatogram of a $20 \mu$ injection of a standard mixture of $10 \mu \mathrm{g} / \mathrm{ml}$ PIT and $20 \mu \mathrm{g} / \mathrm{ml} \mathrm{CAN}$, using the optimized chromatographic conditions

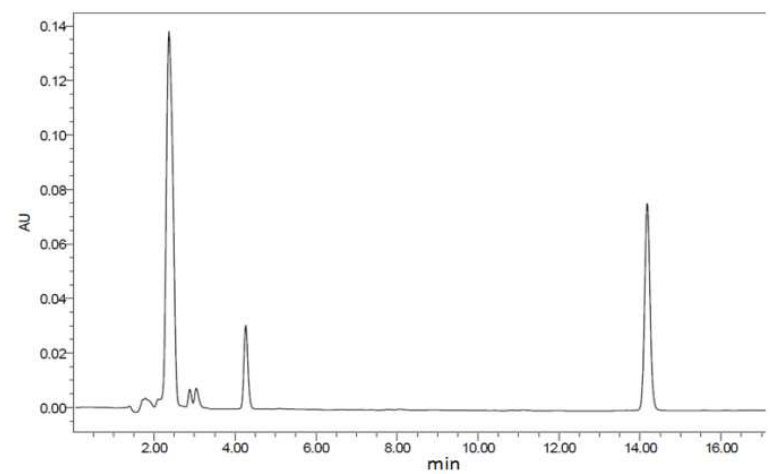

Fig. 13: HPLC chromatogram of a $20 \mu$ injection of a standard mixture of $40 \mu \mathrm{g} / \mathrm{ml} \mathrm{CLO}$ and $10 \mu \mathrm{g} / \mathrm{ml} \mathrm{ROS} \mathrm{using} \mathrm{the} \mathrm{optimized}$ chromatographic conditions

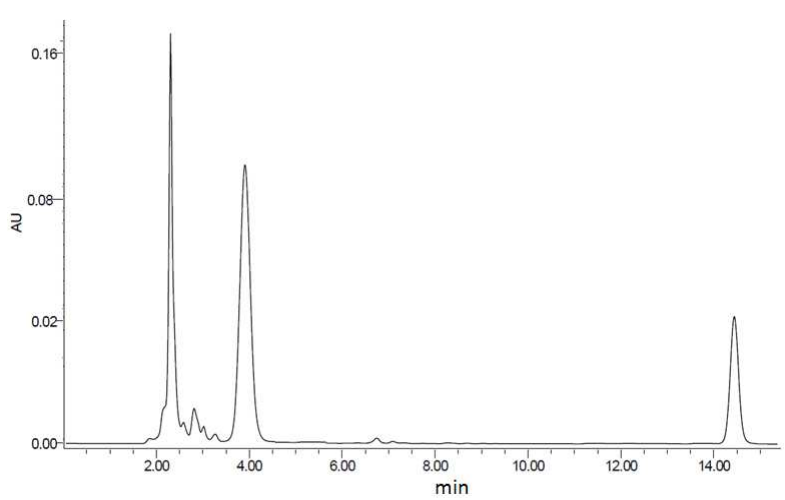

Fig. 14: HPLC chromatogram of a $20 \mu$ injection of a standard mixture of $10 \mu \mathrm{g} / \mathrm{ml}$ PIT and $20 \mu \mathrm{g} / \mathrm{ml} \mathrm{CAN}$, in spiked plasma using the optimized chromatographic conditions

\section{System suitability}

According to FDA 1994 [33], system suitability tests are an integral part of any liquid chromatographic method. System suitability uses to verify capacity factor, a number of theoretical plates, asymmetry factor, selectivity and resolution (table 1) and they were found to be satisfactory and within the reported acceptance criteria listed in the reference. Various parameters including capacity factors $\left(\mathrm{k}^{\prime}\right)$, selectivity $(\alpha)$, resolution $\left(R_{s}\right)$, asymmetry factor $\left(A_{f}\right)$ and number of theoretical plates $(\mathrm{N})$ are listed in table 1 . All these parameters were satisfactory and indicative of the good efficiency and selectivity of the method for separation of CLO-ROS or PIT-CAN binary mixtures.

\section{Method validation and statistical analysis $[34,35]$}

The proposed methods were validated according to ICH guidelines [35]. Using the method of least squares, regression equations, correlation coefficients, limits of detection (LOD) and quantification (LOQ) were calculated. The high values of the correlation coefficient (r) with negligible intercepts indicate the good linearity of the calibration graphs. The standard deviation of residuals $\left(\mathrm{S}_{\mathrm{y} / \mathrm{x}}\right)$, of intercept $\left(\mathrm{S}_{\mathrm{a}}\right)$ and of slope $\left(\mathrm{S}_{\mathrm{b}}\right)$ are presented for CLO, ROS, PIT or CAN. $\left(\mathrm{S}_{\mathrm{y} / \mathrm{x}}\right)$ is a measure of the extent of deviation of the found (measured) y-values from the calculated ones. Also, the small degree of scattering of the experimental data point around the line of regressions was confirmed by the small values of the variances around the slopes $\left(\mathrm{S}_{\mathrm{b}}{ }^{2}\right)$.

Table 1: HPLC system suitability parameters for the determination of CLO-ROS and PIT-CAN using the proposed RP-HPLC method

\begin{tabular}{llllll}
\hline Analyte & $\begin{array}{l}\text { Retention time } \\
\left(\mathbf{t}_{\mathbf{R}}\right)\end{array}$ & $\begin{array}{l}\text { Capacity factor } \\
\left(\mathbf{k}^{\prime}\right)\end{array}$ & $\begin{array}{l}\mathbf{N}^{\circ} \text { of theoretical plates } \\
(\mathbf{N})\end{array}$ & $\begin{array}{l}\text { Asymmetry factor } \\
\left(\mathbf{A}_{\mathbf{F}}\right)\end{array}$ & $\begin{array}{l}\text { Selectivity } \\
(\boldsymbol{\alpha})\end{array}$ \\
\hline ROS & 3.9 & 0.44 & 1156 & 1.10 & $\begin{array}{l}\text { Resolution } \\
\left(\mathbf{R}_{\mathbf{s}}\right)\end{array}$ \\
CLO & 14.4 & 3.82 & 4624 & 1.14 & 21.7 \\
PIT & 4.2 & 0.34 & 1479 & 1.03 & 1.68 \\
CAN & 13.9 & 3.96 & 25090 & 1.00 \\
\hline
\end{tabular}

\section{Linearity and concentration range}

Under the described experimental conditions, the graphs obtained by plotting FF, FFR (in the case of chemometric methods) or the peak area (in case of the RP-HPLC method) each versus concentration of CLO, ROS, PIT or CAN gave linear relationships over the concentration ranges stated in tables 2 and 3, respectively. The slopes, intercepts and correlation coefficients obtained by the linear least squares treatments of the results are also given in tables 2 and 3. The correlation coefficients (r) obtained were higher than 0.999 for the drugs with high values of $F$ (low significant $F$ ) which confirmed the linearity of the calibration curves. An important statistical parameter for indicating the random error in the estimated values of $y$ is the standard deviation of the residuals $S_{y / x}$. Also, the importance of $S_{y / x}$ originates from being used to calculate $S_{a}$ and $S_{b}$, the standard deviation of the intercept (a) and the slope (b). These values showed the good linearity of the calibration graphs and the compliance to Beer's law.

\section{Limit of detection (LOD) and limit of qualification (LOQ)}

Limits of detection (LOD) and quantification (LOQ) were calculated according to the ICH guidelines [34]. LOD was defined as $10 \mathrm{~S} / \mathrm{b}$, where $S_{a}$ is the standard deviation of the intercept and $b$ is the slope of the calibration curve. The sensitivity of the proposed methods can be confirmed by the low LOD and LOQ values obtained in tables 2 and 3. The variance test for the regression lines revealed that, for equal degrees of freedom, the increase in the variance ratio (Fvalues) means an increase in the mean squares due to regression and a decrease in the mean squares due to residuals, (i. e the less is 
the scatter of experimental points around the regression line). Consequently, regression lines with high F-values (low significance
F) are much better than those with lower ones. Good regression lines show high values for both $\mathrm{r}$ and $\mathrm{F}$ statistical parameters [36].

Table 2: Assay parameters for the determination of CLO-ROS or PIT-CAN using the applied chemometric assisted methods

\begin{tabular}{|c|c|c|c|c|c|c|c|c|}
\hline & CLO & & ROS & & CAN & & PIT & \\
\hline Parameters & FF & FFR & FF & FFR & FF & FFR & FF & FFR \\
\hline Conc. Range $(\mu \mathrm{g} / \mathrm{ml})$ & $10-50$ & $10-50$ & $4-20$ & $4-20$ & $8-20$ & $8-20$ & $2-10$ & $2-10$ \\
\hline$\lambda$ range(nm) & $241-269$ & $237-265$ & $241-269$ & $237-265$ & $236-278$ & $258-278$ & $236-278$ & $258-278$ \\
\hline$\Delta \lambda_{(\mathrm{nm})}$ & 4 & 4 & 4 & 4 & 6 & 4 & 4 & 4 \\
\hline $\mathrm{LOD}(\mu \mathrm{g} / \mathrm{ml})$ & $-3.00 \times 10^{-4}$ & $8.68 \times 10^{-3}$ & $1.64 \times 10^{-5}$ & $-1.2 \times 10^{-4}$ & $-8.42 \times 10^{-3}$ & $-4.98 \times 10^{-2}$ & $-0.23 \times 10^{-3}$ & $3.62 \times 10^{-3}$ \\
\hline $\mathrm{LOQ}(\mu \mathrm{g} / \mathrm{ml})$ & $-1.00 \times 10^{-3}$ & $2.89 \times 10^{-2}$ & $5.47 \times 10^{-5}$ & $-3.9 \times 10^{-4}$ & $-0.28 \times 10^{-1}$ & -0.166 & $-0.78 \times 10^{-3}$ & $0.121 \times 10^{-1}$ \\
\hline Intercept (a) & $3.01 \times 10^{-2}$ & $6.48 \times 10^{-2}$ & $1.91 \times 10^{-2}$ & -0.126 & $-0.83 \times 10^{-3}$ & $-0.23 \times 10^{-3}$ & $6.59 \times 10^{-2}$ & -0.139 \\
\hline Slope (b) & -679 & 28.81 & $8.75 \times 10^{-2}$ & 0.119 & -0.247 & -0.0475 & -2219 & 132.3 \\
\hline $\mathrm{r}$ & 0.9999 & 0.9999 & 0.9999 & 0.9998 & 0.9996 & 0.9995 & 0.9990 & 0.9990 \\
\hline $\mathrm{S}_{\mathrm{a}}$ & $6.76 \times 10^{-2}$ & $8.37 \times 10^{-2}$ & 15978 & -3064 & $6.92 \times 10^{-4}$ & $0.788 \times 10^{-3}$ & 0.173 & 0.159 \\
\hline$S_{b}$ & 3.46 & 0.182 & 105 & 27.39 & $3.23 \times 10^{-3}$ & $0.714 \times 10^{-3}$ & 58.4 & 3.12 \\
\hline$S_{y / x}$ & $1.25 \times 10^{-2}$ & $1.91 \times 10^{-2}$ & $2.09 \times 10^{-2}$ & -1.05 & $9.18 \times 10^{-7}$ & $1.21 \times 10^{-6}$ & $8.29 \times 10^{-2}$ & $6.69 \times 10^{-2}$ \\
\hline$\left(S_{b}\right)^{2}$ & 12 & $3.31 \times 10^{-2}$ & 11125 & 750 & $1.04 \times 10^{-5}$ & $5.1 \times 10^{-7}$ & 3410 & 9.78 \\
\hline $\mathrm{S}_{\mathrm{b}} \%$ & 346 & 18.1 & 10547 & 2739 & 0.323 & $0.714 \times 10^{-1}$ & 5840 & 312 \\
\hline $\mathrm{F}$ & 38323 & 25095 & 22948 & 12519.8 & 5952 & 4422 & 1444 & 1791 \\
\hline Significance F & $2.94 \times 10^{-7}$ & $5.55 \times 10^{-7}$ & $6.34 \times 10^{-7}$ & $1.57 \times 10^{-6}$ & $1.75 \times 10^{-7}$ & $3.06 \times 10^{-7}$ & $4.01 \times 10^{-5}$ & $2.9 \times 10^{-5}$ \\
\hline
\end{tabular}

Table 3: Assay parameters for the determination of CLO-ROS and PIT-CAN using the proposed RP-HPLC method in pure drugs and in spiked plasma

\begin{tabular}{|c|c|c|c|c|c|c|c|c|}
\hline & Pure drugs & & & & Spiked pla & & & \\
\hline Parameters & CLO & ROS & PIT & CAN & $\mathrm{CLO}$ & ROS & PIT & CAN \\
\hline Conc range $(\mu \mathrm{g} / \mathrm{ml})$ & $0.1-0.5$ & $0.04-0.2$ & $0.05-0.1$ & $0.5-1$ & $0.1-0.5$ & $0.04-0.2$ & $0.05-0.1$ & $0.5-1$ \\
\hline$\lambda(\mathrm{nm})$ & 220 & 220 & 238 & 238 & 220 & 220 & 238 & 238 \\
\hline $\operatorname{LOD}(\mu \mathrm{g} / \mathrm{ml})$ & 2.31 & 0.70 & 0.09 & 1.39 & 1.37 & 0.17 & 1.37 & 1.37 \\
\hline $\mathrm{LOQ}(\mu \mathrm{g} / \mathrm{ml})$ & 7.70 & 2.3 & 0.31 & 4.64 & 4.59 & 0.58 & 4.59 & 4.59 \\
\hline Intercept (a) & 39.6 & -464 & 1963 & 15394 & 2768 & -910 & 1862 & -9622 \\
\hline Slope (b) & 24252 & 15647 & 39305 & 19342 & 24067 & 15862 & 39458 & 21110 \\
\hline $\mathrm{r}$ & 0.9991 & 0.9995 & 0.9999 & 0.9990 & 0.9997 & 0.9999 & 0.9999 & 0.999347 \\
\hline $\mathrm{S}_{\mathrm{a}}$ & 18681 & 3671 & 1255 & 8983 & 11062 & 922 & 1568 & 7934 \\
\hline$S_{b}$ & 563 & 276 & 189 & 611 & 333 & 69 & 236 & 539 \\
\hline$S_{y / x}$ & $9.52 \times 10^{8}$ & $3.67 \times 10^{7}$ & 4.29 & $59.78 \times 10^{6}$ & 3.34 & $2.32 \times 10^{6}$ & $6.70 \times 10^{6}$ & $4.66 \times 10^{7}$ \\
\hline$\left(\mathrm{S}_{\mathrm{b}}\right)^{2}$ & 317281 & 76587 & 35832 & 373661 & 111253 & 4840 & 111253 & 111253 \\
\hline$\% \mathrm{~S}_{\mathrm{b}}$ & 56327 & 27674 & 18929 & 61127 & 33354 & 6957 & 23639 & 53985 \\
\hline $\mathrm{F}$ & 1853 & 3196 & 43114 & 1001 & 5206 & 51981 & 27862 & $4.6 \times 10^{7}$ \\
\hline Significance F & $2.76 \times 10^{-5}$ & $1.22 \times 10^{-5}$ & $2.46 \times 10^{-7}$ & $9.97 \times 10^{-4}$ & $5.87 \times 10^{-6}$ & $1.86 \times 10^{-7}$ & $4.74 \times 10^{-7}$ & $6.53 \times 10^{-4}$ \\
\hline
\end{tabular}

Table 4: Assay results for the determination of CLO-ROS or PIT-CAN in synthetic mixtures using the proposed assisted chemometric methods

\begin{tabular}{|c|c|c|c|c|c|}
\hline \multirow[t]{2}{*}{ Ratio CLO: ROS } & \multicolumn{2}{|c|}{ Mean recovery $\pm S D^{a}$ RSD $\%^{b} \operatorname{Er}^{c}{ }^{c}$} & \multirow[t]{2}{*}{ Ratio CAN: PITA } & \multicolumn{2}{|c|}{ Mean recovery \pm SD $^{a}$ RSD $\%^{b} \operatorname{Er} \%^{c}$} \\
\hline & FF & FFR & & FF & FFR \\
\hline \multirow[t]{3}{*}{$30: 4$} & $101.13 \pm 1.45$ & $99.94 \pm 1.52$ & $2: 1$ & $100.00 \pm 0.86$ & $100.08 \pm 0.73$ \\
\hline & 1.43 & 1.52 & & 0.86 & 0.73 \\
\hline & 1.13 & -0.06 & & 0.00 & 0.08 \\
\hline \multirow[t]{3}{*}{$30: 8$} & $101.90 \pm 1.34$ & $98.73 \pm 1.68$ & $4: 1$ & $99.03 \pm 0.61$ & $100.20 \pm 0.54$ \\
\hline & 1.32 & 1.70 & & 0.61 & 0.54 \\
\hline & 1.90 & -1.27 & & -0.97 & 0.20 \\
\hline \multirow[t]{3}{*}{$30: 12$} & $100.95 \pm 0.98$ & $100.00 \pm 0.75$ & $4: 3$ & $100.98 \pm 0.53$ & $99.45 \pm 0.78$ \\
\hline & 0.97 & 0.75 & & 0.53 & 0.78 \\
\hline & 0.95 & 0.00 & & 0.98 & -0.45 \\
\hline \multirow[t]{3}{*}{$30: 16$} & $101.70 \pm 1.32$ & $100.22 \pm 1.32$ & $8: 1$ & $98.52 \pm 0.76$ & $100.00 \pm 0.63$ \\
\hline & 1.29 & 1.32 & & 0.77 & 0.63 \\
\hline & 1.70 & 0.22 & & -1.48 & 0.00 \\
\hline \multirow[t]{3}{*}{$30: 20$} & $102.28 \pm 0.86$ & $100.46 \pm 0.68$ & $8: 3$ & $100.45 \pm 0.89$ & $99.35 \pm 0.99$ \\
\hline & 0.84 & 0.67 & & 0.89 & 0.99 \\
\hline & 2.28 & 0.46 & & 0.45 & 0.65 \\
\hline \multirow[t]{3}{*}{$30: 30$} & $102.84 \pm 0.87$ & $100.34 \pm 0.54$ & $8: 5$ & $95.94 \pm 0.89$ & $100.52 \pm 0.42$ \\
\hline & 0.82 & 0.54 & & 0.92 & 0.42 \\
\hline & 2.84 & 0.34 & & -4.06 & 0.52 \\
\hline
\end{tabular}

amean \pm SD for the three determinations, b\% Relative standard deviation, ${ }^{\mathrm{c}} \%$ Relative error

\section{Accuracy and precision}

In order to assess the accuracy of the proposed methods, synthetic mixtures with different ratios of CLO-ROS and PIT-CAN were analyzed. The percentage recoveries, obtained for each mixture, are given in tables 4,5 and 6 . first derivative $\left(D_{1}\right)$, second derivative $\left(D_{2}\right)$ and the derivative ratio $\left(\mathrm{D}_{1} \mathrm{R}\right)$ were also applied to the studied mixtures. The spectral interferences in the determination of CLOROS or PIT-CAN in the presence of each other were only partially corrected using the $\mathrm{D}_{1}$ and $\mathrm{D}_{2}$ methods, where unacceptable 
percentage recoveries were obtained for mixtures containing higher ratios of interfering product. Better, but also unacceptable percentage recoveries were obtained by applying the $\mathrm{D}_{1} \mathrm{R}$ method. FF, FFR and RP-HPLC methods (tables 4, 5 and 6) indicate their superiority for correction of spectral interferences in the determination of CLO in the presence of ROS and that of PIT in the presence of CAN. The results indicate that the proposed methods could be applied for the simultaneous determination of CLO-ROS and PIT-CAN in combined dosage form with high accuracy.

Table 5: Accuracy and precision for the simultaneous determination of CLO-ROS in laboratory-made mixtures using the proposed RPHPLC method

\begin{tabular}{|c|c|c|c|c|}
\hline \multirow{3}{*}{$\begin{array}{l}\text { Conc } \mu \mathrm{g} / \mathrm{ml} \\
\text { CLO: ROS }\end{array}$} & \multicolumn{4}{|c|}{ Mean recovery \pm SD $^{\mathrm{a}}, \mathbf{R S D} \%{ }^{\mathrm{b}}, \mathbf{E r} \%^{\mathrm{c}}$} \\
\hline & \multicolumn{2}{|c|}{ Laboratory made mixtures } & \multicolumn{2}{|c|}{ Spiked plasma } \\
\hline & CLO & ROS & CLO & ROS \\
\hline \multirow[t]{3}{*}{$0.3: 0.04$} & $100.02 \pm 1.02$ & $101.12 \pm 0.86$ & $99.61 \pm 0.86$ & $98.34 \pm 1.42$ \\
\hline & 1.02 & 0.85 & 0.87 & 1.44 \\
\hline & 0.02 & 1.12 & -0.39 & -1.66 \\
\hline \multirow[t]{3}{*}{$0.3: 0.08$} & $100.00 \pm 0.68$ & $100.25 \pm 0.92$ & $98.52 \pm 1.52$ & $98.2 \pm 1.52$ \\
\hline & 0.68 & 0.92 & 1.54 & 1.55 \\
\hline & 0.00 & 0.25 & -1.48 & -1.8 \\
\hline \multirow[t]{3}{*}{$0.3: 1.2$} & $100.92 \pm .22$ & $100.27 \pm 1.56$ & $100.58 \pm 1.68$ & $98.66 \pm 1.03$ \\
\hline & 1.21 & 1.55 & 1.66 & 1.05 \\
\hline & 0.92 & 0.27 & 0.58 & -1.34 \\
\hline \multirow[t]{3}{*}{$0.3: 1.6$} & $101.72 \pm 0.92$ & $99.98 \pm 0.61$ & $101.7 \pm 1.00$ & $99.17 \pm 0.81$ \\
\hline & 0.91 & 0.61 & 0.98 & 0.81 \\
\hline & 1.72 & -0.02 & 1.70 & -0.83 \\
\hline \multirow[t]{3}{*}{$0.3: 2$} & $99.98 \pm 1.25$ & $98.55 \pm 0.73$ & $99.61 \pm 1.34$ & $99.44 \pm 1.52$ \\
\hline & 1.25 & 0.74 & 1.35 & 1.52 \\
\hline & -0.02 & -1.45 & -0.39 & -0.51 \\
\hline
\end{tabular}

${ }^{a}$ mean \pm SD for the five determinations, $b \%$ Relative standard deviation, $c \%$ Relative error

Table 6: Accuracy and precision for the simultaneous determination of PIT-CAN in laboratory-made mixtures using the proposed RPHPLC method

\begin{tabular}{|c|c|c|c|c|}
\hline \multirow{3}{*}{$\begin{array}{l}\text { Conc } \mu \mathrm{g} / \mathrm{ml} \\
\text { PIT: CAN }\end{array}$} & \multicolumn{4}{|c|}{ Mean Recovery \pm SD $^{a}$, RSD $^{b}$, Er$^{c}{ }^{c}$} \\
\hline & \multicolumn{2}{|c|}{ Laboratory made mixtures } & \multicolumn{2}{|c|}{ Spiked plasma } \\
\hline & PIT & CAN & PIT & CAN \\
\hline \multirow[t]{3}{*}{$0.3: 0.04$} & $98.92 \pm 0.98$ & $100.39 \pm 0.86$ & $99.98 \pm 0.61$ & $98.2 \pm 1.52$ \\
\hline & 0.99 & 0.86 & 0.61 & 1.55 \\
\hline & -0.58 & 0.39 & -0.02 & -1.8 \\
\hline \multirow[t]{3}{*}{ 0.3:0.08 } & $101.95 \pm 0.97$ & $100.26 \pm 0.92$ & $99.6 \pm 1.09$ & $99.61 \pm 0.73$ \\
\hline & 0.95 & 0.92 & 1.09 & 0.73 \\
\hline & 1.95 & 0.26 & -0.40 & -0.39 \\
\hline \multirow[t]{3}{*}{$0.3: 1.2$} & $101.52 \pm 0.56$ & $100.56 \pm 0.99$ & $99.01 \pm 0.98$ & $101.08 \pm 1.32$ \\
\hline & 0.55 & 0.99 & 0.99 & 1.31 \\
\hline & 1.52 & 0.56 & -0.99 & 1.08 \\
\hline \multirow{3}{*}{$0.3: 1.6$} & $98.21 \pm 1.93$ & $98.10 \pm 1.12$ & $99.66 \pm 0.67$ & $99.6 \pm 1.09$ \\
\hline & 1.96 & 1.14 & 0.68 & 1.09 \\
\hline & -1.01 & -1.9 & -0.34 & -0.40 \\
\hline \multirow[t]{3}{*}{$0.3: 2$} & $100.01 \pm 1.54$ & $99.44 \pm 1.38$ & $98.08 \pm 1.28$ & $99.82 \pm 0.88$ \\
\hline & 1.54 & 1.38 & 1.31 & 0.88 \\
\hline & 0.10 & -0.51 & -1.92 & -0.18 \\
\hline
\end{tabular}

${ }^{a}$ mean \pm SD for the five determinations, b\% Relative standard deviation, c\% Relative error

Table 7: Assay results for CLO, ROS, PIT and CAN in their commercial preparations using the proposed methods

\begin{tabular}{|c|c|c|c|}
\hline & \multicolumn{3}{|c|}{ Mean Recovery $\pm \mathrm{SD}^{\mathrm{a}}, \mathrm{RSD} \%{ }^{\mathrm{b}}, \mathrm{Er}^{\mathrm{c}}{ }^{\mathrm{c}}$} \\
\hline & HPLC (220 nm) & FF (241-269 nm) & FFR (237-265 nm) \\
\hline CLO & $100.26 \pm 0.15$ & $100.59 \pm 0.22$ & $100.82 \pm 0.47$ \\
\hline$* *$ t-test & 0.15 & 0.22 & 0.47 \\
\hline \multirow[t]{4}{*}{ **F-test } & 0.26 & 0.59 & 0.82 \\
\hline & - & 0.035 & 0.12 \\
\hline & - & 2.13 & 1.28 \\
\hline & HPLC (220 nm) & FF (241-269 nm) & FFR $(237-265 \mathrm{~nm})$ \\
\hline ROS & $99.6 \pm 0.42$ & $100.32 \pm 0.24$ & $99.59 \pm 0.37$ \\
\hline$* *$ t-test & 0.42 & 0.24 & 0.37 \\
\hline \multirow[t]{4}{*}{${ }^{* *} \mathbf{F}$-test } & 0.40 & 0.32 & 0.41 \\
\hline & - & 0.118 & 0.158 \\
\hline & - & 0.33 & 0.78 \\
\hline & HPLC (238 nm) & FF $(236-278 \mathrm{~nm})$ & FFR $(258-278 \mathrm{~nm})$ \\
\hline PIT & $100.26 \pm 0.15$ & $100.59 \pm 0.22$ & $100.82 \pm 0.47$ \\
\hline$* *$ t-test & 0.15 & 0.22 & 0.47 \\
\hline
\end{tabular}




\begin{tabular}{llll}
\hline$* *$ F-test & 0.26 & 0.59 & 0.82 \\
& - & 0.035 & 0.12 \\
& - & 2.13 & 1.28 \\
CAN & HPLC (238 nm) & FF (236-278 $\mathbf{~ n m})$ & FFR (258-278 $\mathbf{~ n m ) ~}$ \\
**t-test & $99.6 \pm 0.42$ & $100.32 \pm 0.24$ & $0.59 \pm 0.37$ \\
$* *$ F-test & 0.42 & 0.24 & 0.47 \\
& 0.40 & 0.32 & 0.158 \\
& - & 0.118 & 0.78 \\
\hline
\end{tabular}

${ }^{a}$ mean \pm SD for the five determinations, ${ }^{b} \%$ Relative standard deviation, ${ }^{\mathrm{c}} \%$ Relative error, ${ }^{* *}$ Theoretical values of $\mathrm{t}$-and $\mathrm{F}$-at $\mathrm{P}=0.05$ are 2.13 and 6.93 , respectively.

\section{Laboratory made mixtures}

Laboratory made mixtures were prepared and analyzed by the proposed RP-HPLC and chemometric assisted spectrophotometric methods. The active ingredients were extracted with methanol and dilution was made to reach concentration levels within the specified ranges with the same solvent. By the use of the RP-HPLC method, the active ingredients were eluted at their specific retention times. The dual wavelength detection enabled peak purity verification where no signs of co-elution from any inactive components were detected. The recoveries were calculated using the external standard method. The assay results revealed satisfactory accuracy and precision as indicated from \% recovery, SD and RSD \% by applying both, chemometric and RP-HPLC methods (table 7).

\section{CONCLUSION}

In conclusion, the present work represents an approach for the assay of cardiovascular co-administered drugs CLO-ROS and PITCAN in their binary mixture. The developed Fourier functions (FF or FFR) method depends on convoluting the absorption spectra of the drugs or their ratio signals using combined trigonometric Fourier functions, and the magnitude of Fourier function coefficients is related to the concentration of each drug in its mixture with the other drug. The proposed chemometric methods applied neither the sophisticated instrument nor prior separation steps, with minimal usage of solvents. Such methods are considered as green analytical techniques. These factors encourage the use of such methods for the quality control of these investigated drugs in pharmaceutical companies. The developed RP-HPLC is more sensitive than the applied chemometric methods and was used for the determination the concentration of the studied drugs in spiked plasma. The sensitivity of the RP-HPLC method gives the advantage to quantify the therapeutic dose of drugs in human plasma.

\section{CONFLICTS OF INTERESTS}

Declared none

\section{REFERENCES}

1. De Cates A, Farr M, Wright N. Fixed-dose combination therapy for the prevention of cardiovascular disease. US Natl Libr Med Natl Institutes Heal Pubmed 2014;16:15-8.

2. O'Neil MJ. The merck index an encyclopedia of chemicals, drugs, and biologicals senior; 2001.

3. Herbert JM, Frehel D, Vallee E. Cardiovascular drug reviews. Cardiovasc Drug Rev 1993;11:180-98.

4. Katzung BG. Basic and Clinical Pharmacology. Eighth ed; 2001.

5. Dermiş S, Aydoğan E. Stability indicating a spectrophotometric method for determination and validation of clopidogrel bisulfate in tablet dosage form. Commun Fac Sci Univ Ankara 2010;1:418-23.

6. Sahoo NK, Sahu M, Rao PS, Indira JN, Rani SN, Ghosh GK. Validation of assay for bulk clopidogrel and for some tablet forms by reverse-phase high-performance liquid chromatography. J Taibah Univ Sci 2014;8:331-6.

7. Derm S. Rapid and accurate determination of clopidogrel in tablets by using spectrophotometric and chromatographic techniques 2009;55:1-16.

8. Takahashi M, Pang H, Kawabata K, Farid AN, Kurihara A. Quantitative determination of clopidogrel active metabolite in human plasma by LC-MS/MS. J Pharm Biomed Anal 2008;48:1219-24.

9. Krishna Reddy Ch Sai, Tulasi BVD, Rohini A, Shanta K. Simultaneous estimation of rosuvastatin calcium and clopidogrel bisulfate by UV spectroscopy. Int J ChemTech Res 2013;5:127-30.

10. Rajput S, George R, Ruikar B. Chemometric simultaneous estimation of clopidogrel bisulfate and aspirin from combined dosage form. Indian J Pharm Sci 2008;70:450-4.

11. Mohamed SH, Issa YM, Magdy AI. H-point standard addition method for the simultaneous determination of clopidogrel bisulfate in a mixture with aspirin. Int J Res Pharm Chem 2015;5:289-94.

12. De Cates A, Farr M, Wright N. Bio-analytical determination of clopidogrel and pantoprazole by RP-HPLC method in rat plasma : application to drug interaction study. Asian J Pharm Clin Res 2015;7:10.

13. Donthula S, Kumar MK, Teja GS, Kumar YM, Krishna JY, Ramesh D. Spectrophotometric determination of rosuvastatin calcium in the marketed formulation. Sch Res Libr 2011;3:350-6.

14. Shekhar MC, Babu GR, Dinda SC, Sonthosh PV, Shwetha P. Estimation of rosuvastatin calcium in bulk and tablet dosage. J Appl Pharm 2014;4:335-9.

15. Turabi ZM, Khatatbeh OA. Stability indicating RP-HPLC method development and validation for the determination of rosuvastatin calcium in pharmaceutical dosage form. Int J Pharm Sci Drug Res 2014;6:154-9.

16. Trivedi HK, Patel MC. Development and validation of a stabilityindicating RP-UPLC method for determination of rosuvastatin and related substances in pharmaceutical dosage form. Sci Pharm 2012;80:393-406.

17. El-Gizawy SM. Development and validation of HPLC method for simultaneous determination of amlodipine, valsartan, hydrochlorothiazide in the dosage form and spiked human plasma. Am J Anal Chem 2012;3:422-30.

18. Banerjee SK, Vasava NM. Simultaneous estimation of amlodipine and rosuvastatin in combined bulk forms by RPHPLC using ultraviolet detection. Bull Pharm Res 2013;3:29-33.

19. Malakondaiah DS, Ranjeetkumar V, Naveenkumar M, Ram AS, Reddy TRM, Rao VUM. Research article development and validation of stability indicating RP-HPLC Method for simultaneous estimation of rosuvastatin and clopidogrel in pharmaceutical dosage form. Int J Pharm Res Rev 2014;3:13-21.

20. Badawy AM, Mostafa NM, Elaziz A, Elaleem, Abd B, Lamie NT. Stability-indicating PLS and PCR chemometric methods for the determination of rosuvastatin in the presence of its two acid degradation products. Int J Pharm Pharm Sci 2011;3:232-7.

21. Muralikrishna C, Rambabu C. Estimation of candesartan cilexetil in bulk and pharmaceutical formulations by using spectrophotometric methods. Asian J Pharm Chem 2014;7:929-32.

22. AL-Arfaj N, AL-Onazi W, Amina M. Spectrophotometric determination of candesartan cilexetil in the presence of its alkaline induced degradation product. Asian J Chem 2011;23:1696-700.

23. Bhadke Tejaswini K, Mohite Shrinivas K, Magdum Chandrakant S. Simultaneous estimation of candesartan cilexetil and 
hydrochlorothiazide in tablet dosage form by UV spectrophotometric method. Int J PharmTech Res 2012;4:786-90.

24. Hassan E, Jamal MK, Sayed MA. Stability indicating spectrophotometric assay of candesartan cilexetil and olmesartan medoxomil using discrete fourier transform convoluted curves. Int J Pharm Pharm Sci 2014;6:343-53.

25. Daharwal SJ, Singh VD. Development of a classical least square method for the determination of candesartan and hydrochlorthiazide in tablet dosage form. Asian J Pharm Res 2015;5:90.

26. Patel J, Dave JB, Patel CN. Q-analysis spectrophotometric methods for estimation of candesartan cilexetil and hydrochlorothiazide in tablet dosage form. J Chem Pharm Res 2010;2:10-4.

27. Mukthinuthalapati MA, Sai J, Kumar P. Simultaneous derivative spectrophotometric determination of candesartan cilexetil and hydrochlorothiazide. Pharm Methods 2015;6:148-51.

28. Kishore Kumar H, Pankaj K, Satyanarayana V, Venkateswarlu V. LC-MS/MS method for simultaneous estimation of candesartan and hydrochlorothiazide in human plasma and its use in clinical pharmacokinetics. Bioanalysis 2012;4:95-1204.

29. Sujatha K, Rao JV, Polytechnic G. A new validated stabilityindicating RP-HPLC method for the estimation of pitavastatin in tablet dosage forms. Int J Pharm Anal Res 2014;3:67-74.

30. Virupaxappa BS, Shivaprasad KH, Latha MS. Novel spectrophotometric method for the assay of pitavastatin calcium in pharmaceutical formulations. Der Chem Sin 2011;2:1-5.
31. Wahbi AA, Hassan E, Hamdy D, Fathy E, Barary M. Application of orthogonal functions to pharmaceutical analysis, generation of derivative curves. Saudi Pharm J 2005;13:14-33.

32. Wahbi AM, Abdine H, Korany MA, El yazby F. Spectrophotometric determination of chloramphenicolsulphacetamide in eye drops. Pharmazie 1978;33:721-2.

33. FDA Center for drug evaluation research (CDER), Reviewer Guidance: Validation of Chromatographic Methods, Washington, USA; 1994.

34. Validation of Analytical Procedures: Text and Methodology. International Conference on HarmonisationICH Harmonised Tripartite Guideline. Q2(R1). Geneva; 1995.

35. ICH, "Validation of Analytical Procedures: Text and Methodology", Q2(R1); 2005.

36. P and Berry G. Statistical Methods in Medical research. 4th ed.; 2002.

\section{How to cite this article}

- Marwa K EL Jamal, Azza A Gazy. Comparative study of rp-hplc method versus fourier transform convolution chemometric methods; an application on pharmaceutical binary mixtures of candesartan cilexetil-pitavastatin calcium and clopidogrel bisulfate-rosuvastatin calcium. Int J Pharm Pharm Sci 2016;8(10):125-133. 